\title{
Primary Sarcoma of the Specialised Prostatic Stroma: A Case Report and Review of the Literature
}

\author{
Rosanna Zamparese, ${ }^{1}$ Francesco Corini, ${ }^{1}$ Antonio Braccischi, ${ }^{1}$ Antonella D'Angelo, ${ }^{1}$ \\ Lucilla Diamanti, ${ }^{1}$ Marina Del Vecchio, ${ }^{1}$ Willy Giannubilo, ${ }^{2}$ and Vladimiro Mambelli ${ }^{1}$ \\ ${ }^{1}$ Departments of Pathology, General Hospital C.G. Mazzoni, 63100 Ascoli Piceno, Italy \\ ${ }^{2}$ Department of Urology, Central Hospital, 60035 Jesi, Italy \\ Correspondence should be addressed to Rosanna Zamparese, rosannazamparese@libero.it
}

Received 23 August 2011; Accepted 20 September 2011

Academic Editors: D. Cao and D. Tsuruta

Copyright (C 2011 Rosanna Zamparese et al. This is an open access article distributed under the Creative Commons Attribution License, which permits unrestricted use, distribution, and reproduction in any medium, provided the original work is properly cited.

\begin{abstract}
Primary sarcoma tumours of the prostate are rare and are classified, according to their histology, as stromal tumours of uncertain malignant potential (STUMP) and stromal prostatic sarcoma (PS; low and high grade). We describe a case of a 71-yearold man that developed progressive urinary obstruction symptoms and was subjected to a transurethral prostatic resection (TURP). Histologically, there is a diffuse proliferation of epithelioid and spindle cells that showed rare atypical mitotic figures. Immunohistochemically, the neoplastic cells express diffusely CD34 and focally progesterone whereas no immunoreactivity was seen for cytocheratin, desmin, S-100, Bcl-2, chromogranin, CD117, and actin smooth muscle. A final diagnosis of low-grade prostatic stromal sarcoma (LG-PS) was made. This is a really rare neoplasm; in the literature, in fact, to our knowledge, only 6 cases are described and all of these were alive and free of disease at followup. Our patient too is free of disease at 15 months from the diagnosis.
\end{abstract}

\section{Introduction}

Malignant tumours of the prostate other than carcinomas are rare [1], among these primary sarcomas are the most frequently observed.

Primary sarcoma tumors of the prostate arise from specialized hormone-dependent mesenchymal cells [2] and are classified, according to their histology, as stromal tumours of uncertain malignant potential (STUMP) and stromal prostatic sarcoma (PS; namely low grade and high grade) [3-5].

We describe a rare case of low-grade stromal sarcoma (LG-PS) of the specialised prostatic stroma, and we also review the literature concerning these tumours.

\section{Case Report}

A 71-year-old man developed progressive urinary obstruction symptoms and presented at our Hospital. Clinical examination suggested benign prostatic hyperplasia and a transurethral prostatic resection (TURP) was performed.
Macroscopically, the excised tissue consist of many fragments of prostatic tissue weighing 30 grams.

Microscopically, the histological specimens taken after TURP showed a diffuse proliferation of epithelioid and spindle cells, with a storiform and infiltrative growth pattern. There are not prostatic glands in the proliferation, no foci of necrosis, no vascular invasion. The neoplastic cells showed rare atypical mitotic figures in addition to moderate hypercellularity and moderate nuclear atypia with pleomorphism (Figure 1).

Immunohistochemically the neoplastic cells characteristically express diffusely CD34 and focally progesterone whereas no immunoreactivity was seen for cytocheratin (clone AE1-AE3 and Cam 5.2), desmin, S-100, Bcl-2, chromogranin, CD117, and actin smooth muscle (Figure 2).

We evaluated additional immunohistochemical markers for their potential diagnostic and therapeutic utility. Although p53 and Ki-67 showed a very low expression.

On the basis of the morphological and immunohistochemical features, a final diagnosis of LG-PS was made. 


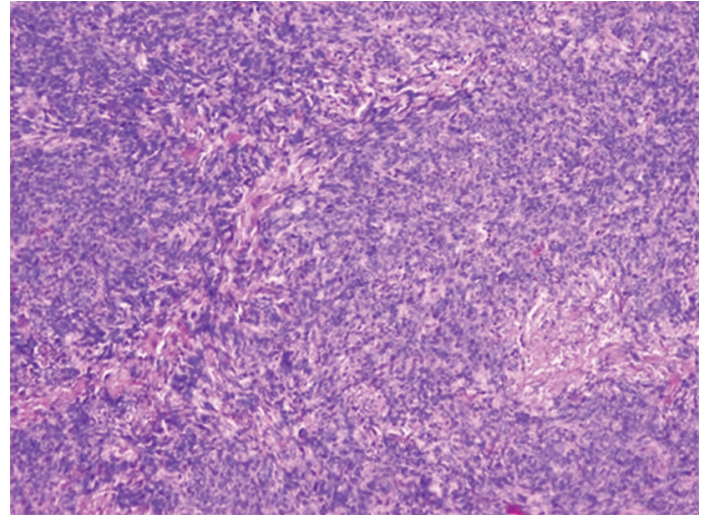

(a)

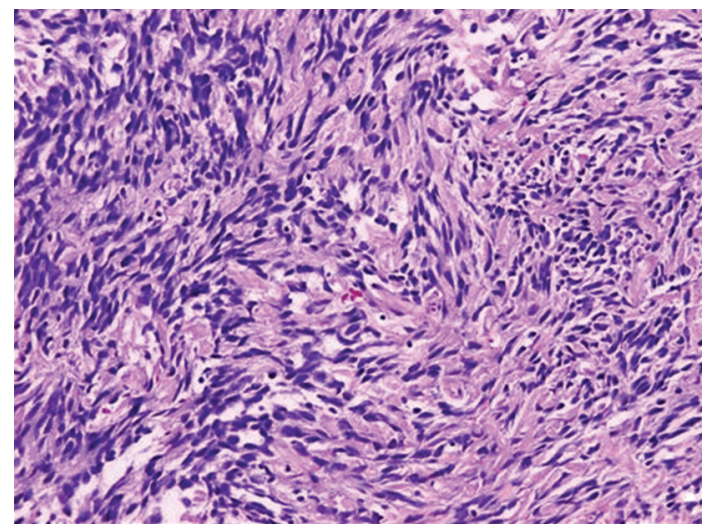

(c)

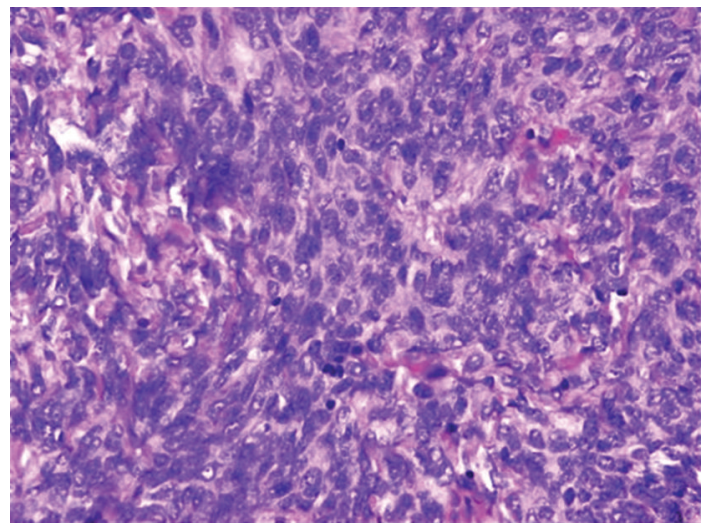

(b)

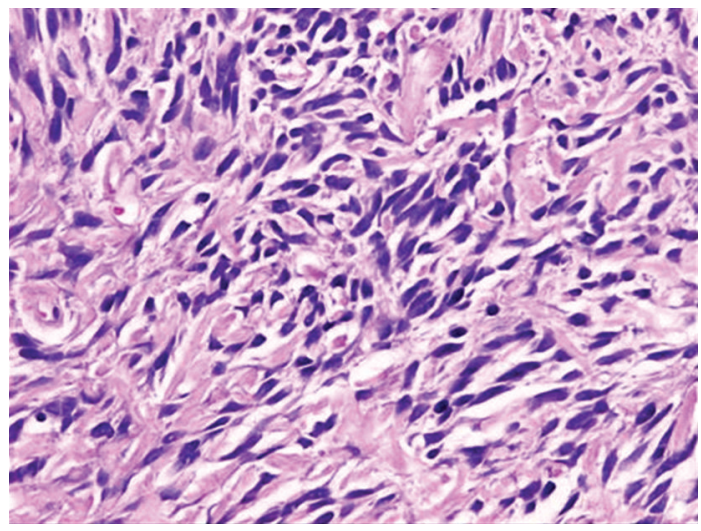

(d)

FIGURE 1: Histological features of low-grade prostatic sarcoma. Diffuse proliferation of epithelioid cells ((a) (10 XHPF) and (b) (40 XHPF)) and spindle cells, with a storiform and infiltrative growth pattern ((c) (20 XHPF) and (d) (40 XHPF)).

\section{Discussion}

Spindle cell lesions of the prostate encompass a broad spectrum of benign and malignant processes. Some are characteristic of this organ and may be benign or malignant, including leiomyoma and leiomyosarcoma, rhabdomyosarcoma, inflammatory myofibroblastic tumour, solitary fibrous tumours, phyllodes tumour, and synovial sarcoma [3-7].

Prostatic stromal tumors, arising from the specialized prostatic stroma, are rare and distinct tumours with diverse histologic pattern. In the past, these tumors have been reported under a variety of terms including atypical stromal hyperplasia, phyllodes type of atypical stromal hyperplasia, and cystic epithelial-stromal tumors [5]. Now these lesions have been classified as lesions of uncertain malignant potential (STUMP) and stromal sarcoma (low grade and high grade) [6].

Because of their rarity and the nonspecific nature of clinical symptoms, their diagnosis is rarely suspected clinically.

Histologically the diagnosis of HG-PS is based on observation of a neoplasm with a proliferation of epithelioid and spindle cells that showed different growth patterns (solid, storiform, epithelioid, short fascicles, spindled, rhabdoid, and malignant phyllode-like). The neoplastic cells showed marked nuclear atypia, mitosis, and necrosis [5]. LG-PS, instead, showed no nuclear atypia and low mitotic rates, can locally invade, despite having relatively bland cytology at times. HG-PS has the potential to be metastasized.

In contrast to stromal sarcoma, the neoplastic nature of STUMPs is controversial. STUMPs may be considered neoplastic based on the observation that they may diffusely infiltrate the prostate gland and extend into adjacent tissues $[8,9]$.

In most cases STUMP is not of an aggressive nature, occasional cases have been documented with an extension into adjacent tissues or recurrence after resection [10].

The predominant pattern of STUMP consists of either normocellular or mildly hypercellular stroma with cytologically degenerative atypical cells associated with benign glands. The currently used classification of STUMP was first proposed in 1998 by Gaudin et al. [4], in which 4 patterns of stroma were described: degenerative atypia, cellular stromal pattern, phyllodes pattern, and stromal predominant/myxoid pattern. As was the case in the initial and subsequent series on STUMP, the degenerative atypia subtype was the most common pattern seen [5].

The epithelial component proliferations occurring within the STUMP, only recently described [11], is histologically normal in $17 \%$ of cases, and there is a tendency toward urothelial and squamous metaplasia in STUMPs 


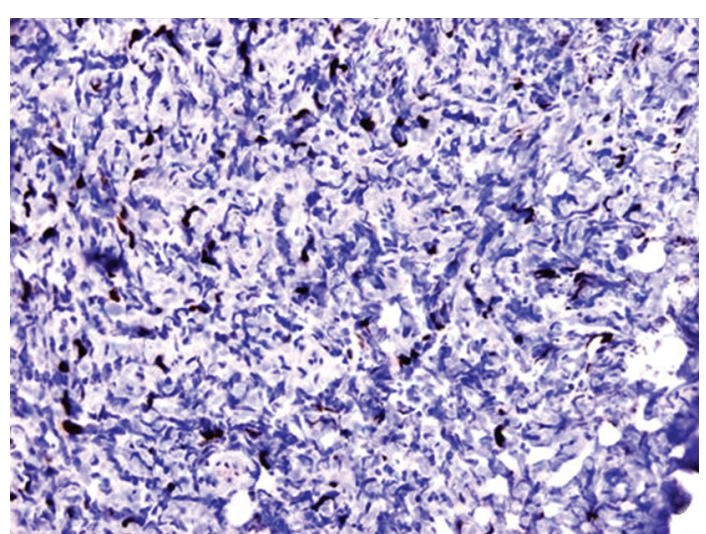

(a)

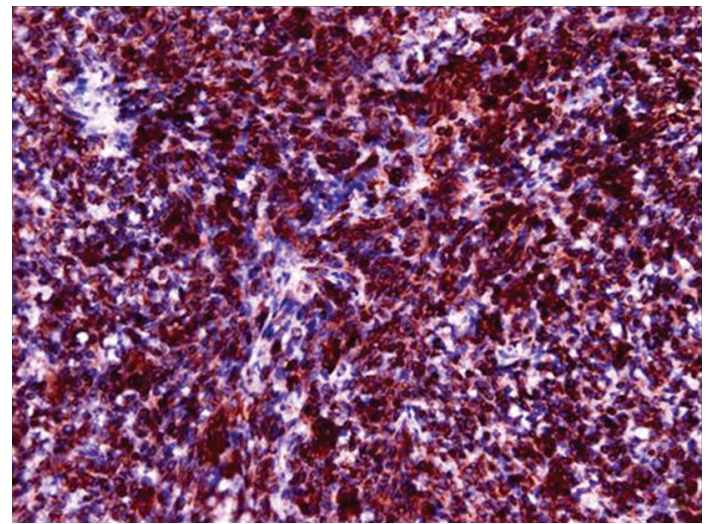

(c)

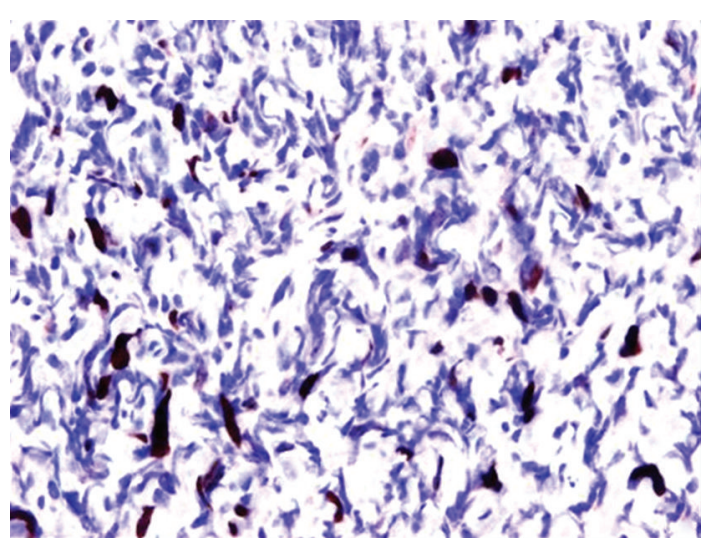

(b)

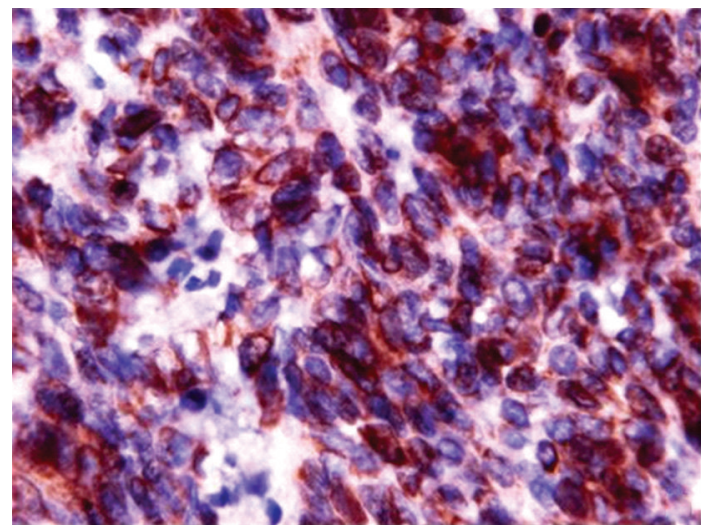

(d)

FIgURE 2: Immunohistochemical expression of CD34 and Ki67. Ki-67 showed a very low expression ((a) (20 XHPF) and (b) (40 XHPF)). The neoplastic cells express diffusely CD34 immunoreactivity ((c) (20 XHPF) and (d) (40 XHPF)).

with a phyllodes pattern, and a prominent basal cell layer in STUMPs with degenerative and cellular stroma [11].

In the past, the histologically pattern of STUMP was often reported as benign prostatic hyperplasia (BPH) with atypia and in rare cases may be difficult to distinguish form stromal sarcoma [5]. Although STUMP can be histologically misdiagnosed as benign prostatic hyperplasia, it is important to recognized that these are neoplasms with unique local morbidity and malignant potential. In contrast to $\mathrm{BPH}$, STUMP can recur frequently and occur at younger men.

Sometimes high- and low-grade prostatic stromal sarcoma was associated with STUMP. Herawi and Epstein, in fact, found that seven (14\%) of the 50 stromal tumours of the prostate that they analyzed were STUMPs associated with sarcoma (4 HG-PS, 3 LG-PS) [5].

There are several difficulties with the histologic diagnosis of STUMP, LG-PS, and HG-PS; it may be difficult to differentiated LG-PS from STUMP, sometimes the tumour seemed histologically benign and only the presence of local infiltration or the presence of atypical mitotic figure was diagnostic of LG sarcoma.

Prognosis and treatment of STUMP and sarcoma are also controversial. Factors to consider in deciding if to proceed with definitive resection for STUMP diagnoses on biopsy include patient's age, presence and size of the lesion, and extent of the lesion, on tissue sampling.

Immunohistochemically, STUMP and stromal sarcomas characteristically express progesterone receptors (PR), and this finding is consistent with their arising from hormonally responsive mesenchymal cells of the prostate $[12,13]$.

Most of these tumors are positive for CD34 [4]. The immunohistochemically strong positivity of CD34 and the negativity of desmin is helpful in the differential diagnosis of STUMP and stromal sarcoma versus smooth muscle tumours [14]. Rarely, gastrointestinal stromal tumors (GIST) may enter the differential diagnosis, but these tumours are CD117 positive while stromal sarcomas are negative [5].

The primary prostatic sarcoma are really rare neoplasms. In the literature, to our knowledge, only 6 cases are described of LG-PS (age: 42 to 76, mean 59; see Table 1), except phyllodes tumour [5-15], and between these cases only three are pure sarcoma, the others are associated with a STUMP. All of the patients with LG-PS were alive and free of disease at followup [5-15].

In the current literature only 16 cases are also reported of HG-PS [5-15].

The HG-PS are more aggressive tumour, in fact only 6 patients of 16 cases, reported in the literature, were free of 
TABLE 1: Review of The literature of low-grade prostatic sarcoma.

\begin{tabular}{|c|c|c|c|c|}
\hline Authors & $\begin{array}{c}\text { Age } \\
\text { (years) }\end{array}$ & $\begin{array}{l}\text { Size }(\mathrm{cm}) \\
\text { weigh }(\mathrm{g})\end{array}$ & $\begin{array}{l}\text { Association } \\
\text { with } \\
\text { STUMP }\end{array}$ & Followup \\
\hline \multirow{6}{*}{$\begin{array}{l}\text { Herawi and } \\
\text { Epstein [5] }\end{array}$} & 75 & $988 \mathrm{~g}$ & Yes & $\begin{array}{l}\text { No evidence of } \\
\text { disease at } 13 \text { months } \\
\text { from diagnosis }\end{array}$ \\
\hline & 63 & $2.5 \mathrm{~cm}$ & Yes & $\begin{array}{l}\text { No evidence of } \\
\text { disease at } 2 \text { years } \\
\text { from diagnosis }\end{array}$ \\
\hline & 76 & $10 \mathrm{~g}$ & Yes & $\begin{array}{l}\text { No evidence of } \\
\text { disease at } 25 \text { months } \\
\text { from diagnosis }\end{array}$ \\
\hline & 42 & $2.5 \mathrm{~cm}$ & $\begin{array}{l}\text { No, pure } \\
\text { sarcoma }\end{array}$ & $\begin{array}{l}\text { No evidence of } \\
\text { disease at } 30 \text { months } \\
\text { from diagnosis }\end{array}$ \\
\hline & 43 & $4 \mathrm{~cm}$ & $\begin{array}{l}\text { No, pure } \\
\text { sarcoma }\end{array}$ & $\begin{array}{l}\text { No evidence of } \\
\text { disease at } 36 \text { months } \\
\text { from diagnosis }\end{array}$ \\
\hline & 43 & $2.7 \mathrm{~cm}$ & $\begin{array}{l}\text { No, pure } \\
\text { sarcoma }\end{array}$ & $\begin{array}{l}\text { No evidence of } \\
\text { disease at } 3 \text { months } \\
\text { from diagnosis }\end{array}$ \\
\hline $\begin{array}{l}\text { Current } \\
\text { paper }\end{array}$ & 71 & $30 \mathrm{~g}$ & $\begin{array}{l}\text { No, pure } \\
\text { sarcoma }\end{array}$ & $\begin{array}{l}\text { No evidence of } \\
\text { disease at } 15 \text { months } \\
\text { from diagnosis }\end{array}$ \\
\hline
\end{tabular}

disease, 3 were alive with pulmonary metastases, 2 were alive with multiple metastases, and 3 died of disease and 2 were lost to followup [5-15].

Our case of LG-PS is the seventh that was described in the literature, and our patient was free of disease at 15 months of followup.

\section{References}

[1] J. I. Epstein and I. A. Sesterhenn, Eds., The World Health Classification of Tumours of the Urinary System and Male Genital Organs, IARC Press, Lyon, France, 2004.

[2] D. G. Bostwick, D. Hossain, J. Qian et al., "Phyllodes tumor of the prostate: long-term followup study of 23 cases," Journal of Urology, vol. 172, no. 3, pp. 894-899, 2004.

[3] J. N. Eble, G. Sauter, J. I. Epstein, and I. A. Sesterhenn, Eds., Pathology and Genetics of Tumours of the Urinary System and Male Genital Organs, IARC Press, Lyon, France, 2004.

[4] P. B. Gaudin, J. Rosai, and J. I. Epstein, "Sarcomas and related proliferative lesions of specialized prostatic stroma: a clinicopathologic study of 22 cases," The American Journal of Surgical Pathology, vol. 22, no. 2, pp. 148-162, 1998.

[5] M. Herawi and J. I. Epstein, "Specialized stromal tumors of the prostate: a clinicopathologic study of 50 cases," The American Journal of Surgical Pathology, vol. 30, no. 6, pp. 694-704, 2006.

[6] F. Fraggetta, P. Pepe, M. L. Giunta, and F. Aragona, "Primary high grade sarcoma of the specialised prostatic stroma: a case report with clinico-pathological considerations," Pathologica, vol. 100, no. 6, pp. 482-484, 2008.

[7] D. E. Hansel, M. Herawi, E. Montgomery, and J. I. Epstein, "Spindle cell lesions of the adult prostate," Modern Pathology, vol. 20, no. 1, pp. 148-158, 2007.
[8] S. Fukuhara, Y. Matsuoka, T. Hanafusa et al., "A case report of prostatic stromal tumor of uncertain malignant potential (STUMP)," Acta Urologica Japonica, vol. 54, no. 5, pp. 377$381,2008$.

[9] Y. Kakuta, Y. Kobayashi, M. Tanaka, K. Yazawa, Y. Harada, and K. Itoh, "A case of prostatic stromal tumor of uncertain malignant potential," Acta Urologica Japonica, vol. 51, no. 12, pp. 843-846, 2005.

[10] J. M. Laturnus, M. Gebhard, M. Sommerauer, D. Jocham, and C. Doehn, "Stromal tumour of uncertain malignant potential of the prostate (STUMP)—a case report," Aktuelle Urologie, vol. 41, no. 3, pp. 197-199, 2010.

[11] M. Nagar and J. I. Epstein, "Epithelial proliferations in prostatic stromal tumors of uncertain malignant potential (STUMP)," The American Journal of Surgical Pathology, vol. 35, no. 6, pp. 898-903, 2011.

[12] J. Brolin, L. Skoog, and P. Ekman, "Immunohistochemistry and biochemistry in detection of androgen, progesterone, and estrogen receptors in benign and malignant human prostatic tissue," Prostate, vol. 20, no. 4, pp. 281-295, 1992.

[13] B. G. Mobbs and Y. Liu, "Immunohistochemical localization of progesterone receptor in benign and malignant human prostate," Prostate, vol. 16, no. 3, pp. 245-251, 1990.

[14] E. Paal and M. Miettinen, "Retroperitoneal leiomyomas: a clinicopathologic and immunohistochemical study of 56 cases with a comparison to retroperitoneal leiomyosarcomas," The American Journal of Surgical Pathology, vol. 25, no. 11, pp. 1355-1363, 2001.

[15] P. Colombo, G. L. Ceresoli, L. Boiocchi et al., "Prostatic stromal tumor with fatal outcome in a young man: histopathological and immunohistochemical case presentation," Rare Tumors, vol. 2, no. 4, pp. 163-166, 2010. 


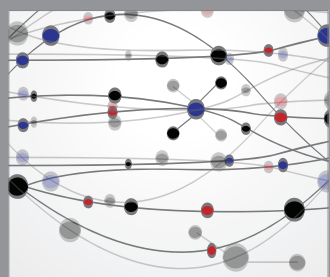

The Scientific World Journal
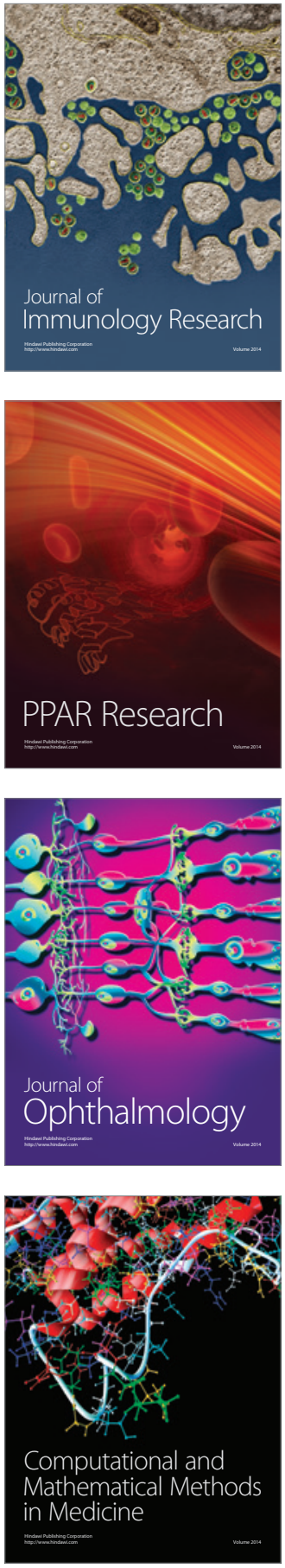

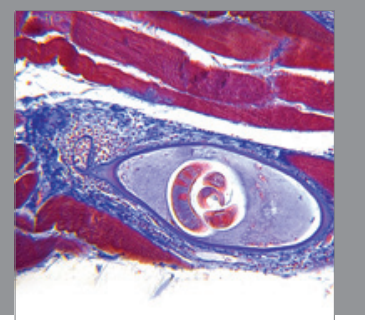

Gastroenterology

Research and Practice
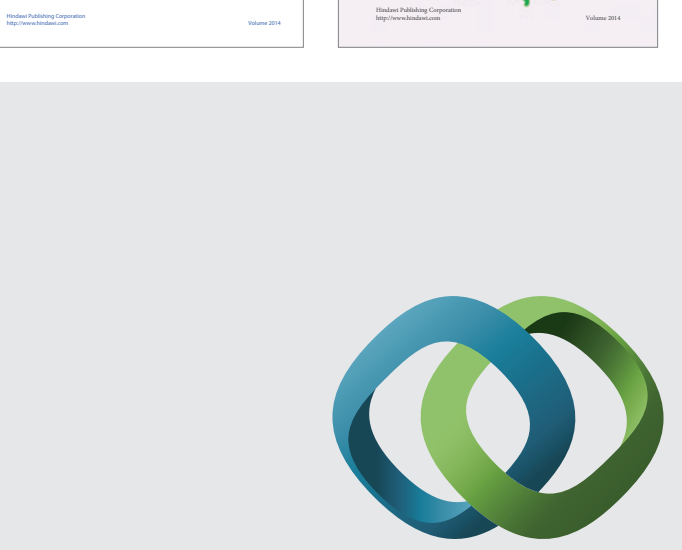

\section{Hindawi}

Submit your manuscripts at

http://www.hindawi.com
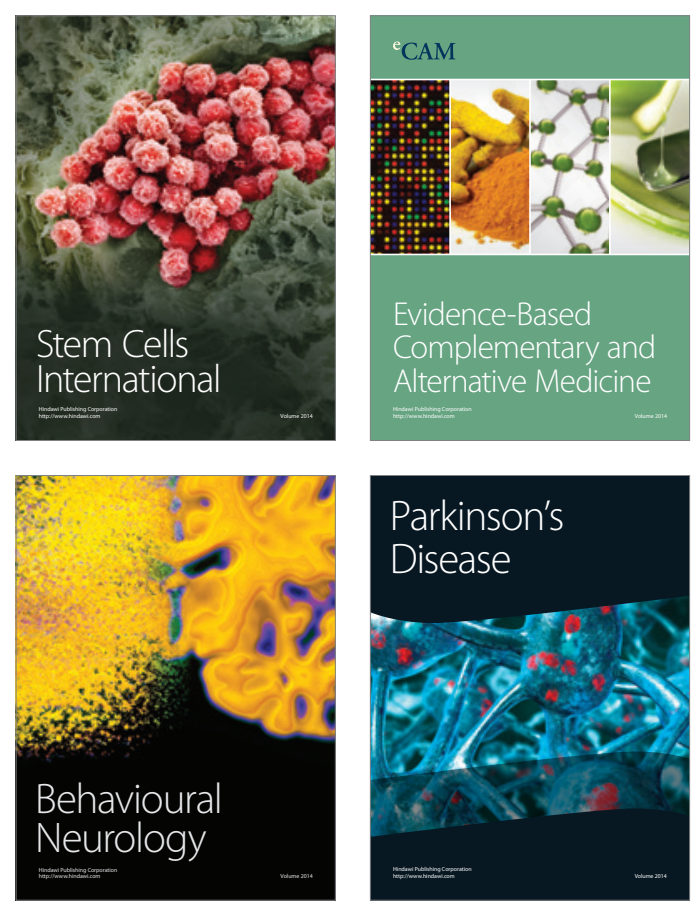

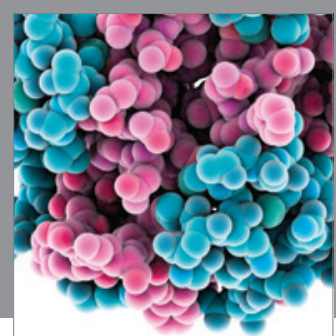

Journal of
Diabetes Research

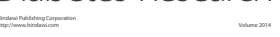

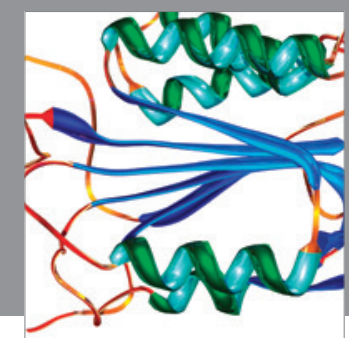

Disease Markers
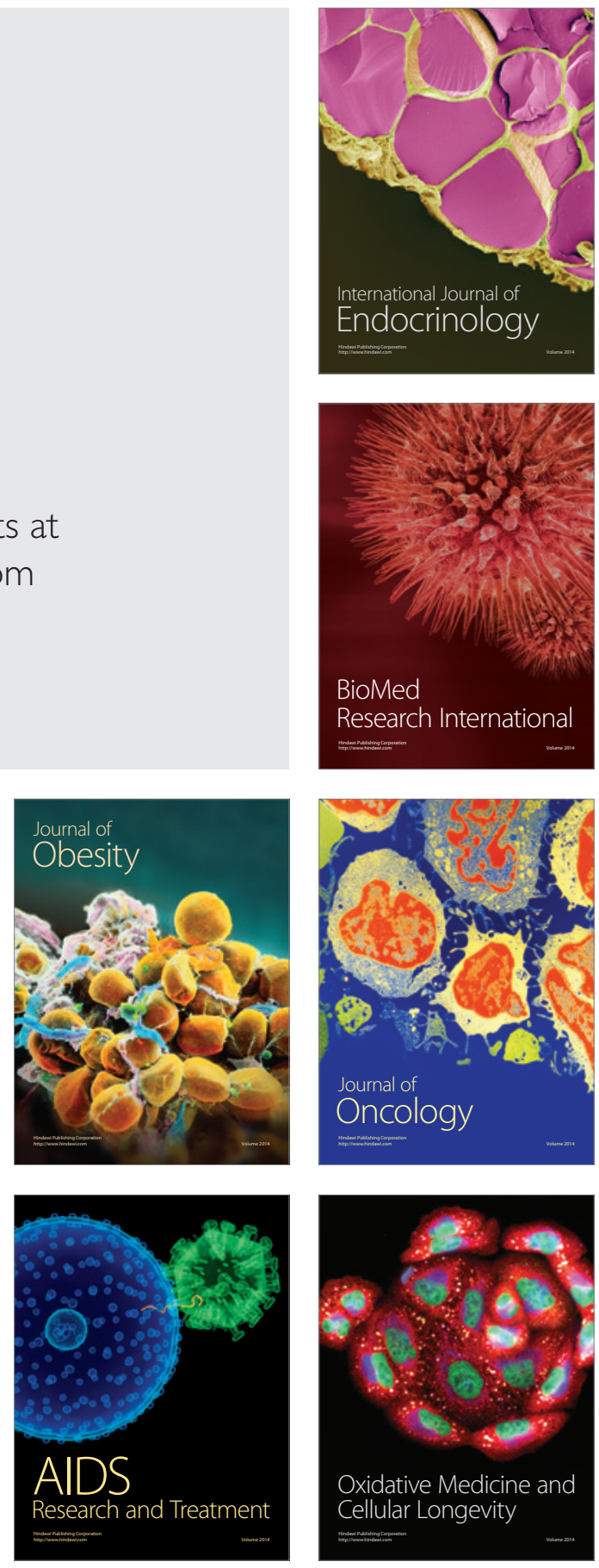